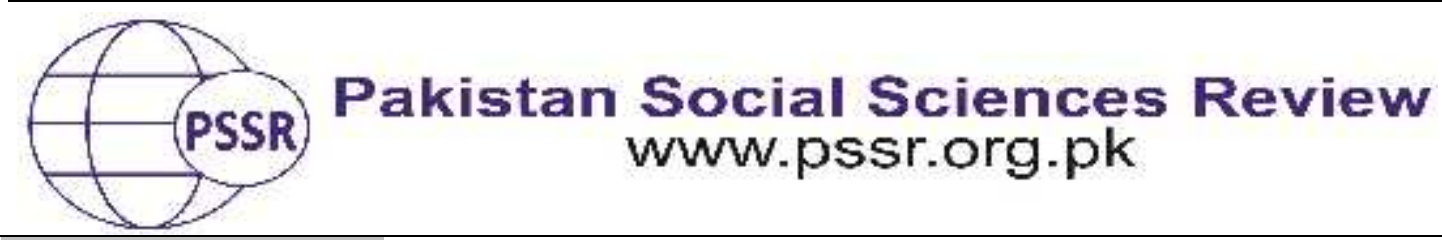

\title{
RESEARCH PAPER \\ Relationship between Smartphone Usage and Psychological Well - Being of Working Women with Different Socioeconomic Background in Punjab- Pakistan
}

\author{
Rooma Shahzadi ${ }^{1}$ Dr. Taimoor ul Hassan ${ }^{2}$
}

1. Ph D Scholar, Faculty of Media and Communication Studies, University of the Central Punjab, Lahore, Pakistan

2. Dean, Faculty of Media and Communication Studies, University of the Central Punjab, Lahore, Pakistan

\begin{tabular}{|c|c|}
\hline & \\
\hline & \multirow{13}{*}{$\begin{array}{l}\text { The study aims to find out the relationship between Smartphone } \\
\text { usage and Psychological well-being among working women } \\
\text { with different socioeconomic background in Punjab Province of } \\
\text { Pakistan. Population of study was ( } \mathrm{n}=600 \text { ) working women } \\
\text { working in different sectors of Punjab-Pakistan. Data was } \\
\text { collected by using Purposive Sampling technique. Two scales } \\
\text { Smartphone addiction Scale (SAS) by Siew Mooi Ching and } \\
\text { Ryff's Psychological well-being scale was used for measuring } \\
\text { the variables. Data was analyzed by using descriptive statistics } \\
\text { and Pearson Correlation coefficient. Results suggested a } \\
\text { significant relationship between Smartphone usage and } \\
\text { psychological wellbeing as ( } \mathrm{r}=.35) \text { while there was a negative } \\
\text { relationship between socioeconomic status, Smartphone usage } \\
\text { and psychological wellbeing. Furthermore, the psychological } \\
\text { well-being could be enhanced by indulging one's self into more } \\
\text { positive utilization of smart phones and avoiding the stress and } \\
\text { anxiety caused by routine chores especially among females. } \\
\text { Study also suggest that if provided with the modern } \\
\text { technologies and social applications, population in Punjab } \\
\text { Province of Pakistan with low socioeconomic status can also } \\
\text { maintain psychological well-being }\end{array}$} \\
\hline & \\
\hline & \\
\hline & \\
\hline & \\
\hline & \\
\hline gical & \\
\hline & \\
\hline & \\
\hline & \\
\hline nding & \\
\hline & \\
\hline & \\
\hline
\end{tabular}

\section{Introduction}

Smartphone is one of the great innovation with respect to technological advancement. Smartphone, is the newest additions to the group of mobile phone family and one of the fastest growing segments of the mobile market, with the smartphone penetration rate achieving $44 \%$ of a developed nation's population (Google \& Ipsos Media CT 2012). Worldwide, smartphone usage is expected to surpass 3 billion in 2020 while according to Statistical Reserach department of 
Pakistan (2016) has forecasted smart phone usage of almost 51\% in year 2020. The smartphone is the fastest growing mobile phone market, with 472 million smartphones sold in the year 2011 alone (Silva 2012).

Smartphones have got a significant place in individual's life, particularly working women. It helps them in their daily communication within their workplace and outside. Although some women have their phones accessible all the time, some others prefer to limit their usage. Despite the fact that innovations have made communication process very easy, but the effects are not restricted to making links via Smartphones but are associated with personality and lifestyle. (Karaaslan\& Budak, 2012). In past, females had little access to technological resources, and they use to spent most of their time in managing household, while time has changed now , and it has revolutionize the overall social structure including the status of women (Hasin , Farzana , Musa \& Hassan , 2018) .

Now the women around the globe as well as of Pakistan is taking active part in the betterment of community and adding in economy. Onu (1998) stated women as the heart of development as, they manage both money economy such as trading, working in formal sector, wage employment and non-economy such as raising children, subsistence agriculture and domestic labor. Women of $21^{\text {st }}$ century are more enthusiastic, determined, active and concerned about the social changes. One of such social change is the growing rate of using smartphone and through it managing professional as well as familial and social life. Negative impacts of smart phone usage have been discussed in past literature, but least focus has been given to positive outcomes associated with smart phone usage. The study focused on identifying the relationship between smart phone usage and psychological wellbeing among working women of Punjab Province of Pakistan.

women accomplish increased control and engagement in decision making which ultimately helps to attain equal foundation with men in various spheressocial, cultural, economic, political and women accomplish increased control and engagement in decision making which ultimately helps to attain equal foundation with men in various spheres-social, cultural, economic, political

Although, excessive usage of smart phone may cause fatigue but on other hand smartphone usage helps them (females) to get distraction from the work related issues and recover from the demands of work through indulging in activities such as music and games on Smart phone (See \&Lasikiewicz, 2013).

So, usage of smartphone also helps in maintaining positive psychological wellbeing. This study aimed to explore associations between smartphone usage and psychological well-being among working women's of Punjab province in Pakistan.

Psychological well-being is a term related to mental relief. It is a combination of positive affective states such as happiness and functioning with optimal effectiveness of individuals in their socioeconomic life (Ryan \& Deci, 2008). Huppert 
(2009) mentions "Psychological wellbeing" is about lives going well. As healthy society is a society of healthy people, so the psychological well-being is associated with the healthy minds of people. An individual with good health, positivity, high self-esteem is considered psychological well. The World Health Organization defines health as a state of complete physical, mental and social well-being and not merely the absence of disease or infirmity (Kesgin \& Topuzoğlu, 2006) .

Psychological well-being was formerly stated as the absence of negative psychological traits such as depression, anxiety, and anger; however, the perspective on the term has changed over time (Yllmaz, 2013). Now it includes certain other characteristics such as optimism, self-esteem, self-efficacy, wish to growth and above all a healthy consciousness. Psychological wellbeing is the requirement of both males and females specially working population and smart phone helps individuals in maintaining psychological wellbeing. As far as females are concerned, with more advancement females have found different ways to maximize their wellbeing and get rid of the negativity and one such medium to fulfill the objective is usage of Smart phones.

\section{Hypotheses} developed.

On the basis of preliminary investigation following hypotheses were

H1. There is a significant relationship between Smartphone usage and psychological well-being of working women in Punjab, Province of Pakistan.

H2. Females from a high social class have more psychological well-being as compared to the females from lower social class due to Smartphone usage.

\section{Literature Review}

This study proposed to discuss relationship between smartphone usage and psychological well - being of working women with different socioeconomic background in Punjab- Pakistan. Previously different researchers have been conducted related to this topic, addressing the relationship between usage of smart phone and psychological wellbeing but this study is indigenous due to its population as well as its focus is on the positive aspects of using technology such as smart phones.

Leung (2015) conducted a study to investigate the effects of smartphones on women's well-being and psychological characteristics and found that use of smartphones positively affects the well-being of women. Hong et al. (2012) also investigated about the psychological characteristics associated with the addictive use of smartphones and found that although anxiety and worries are connected with excessive usage of smart phone. Past researches have also explained that advancement in smart phone sector, which has brought significant negative effects 
on individual's personal, social and emotional development (Adriana \& James, 2005; Yilmaz, et al., 2015; Bianchi \& Philips , 2005; Cetin , 2015). These technological changes have brought difference in life styles, social interaction and emotional well being of females. (Yilmaz, et al., 2015) . Despite its negative outcomes, this advancement has also contributed towards the promotion of positive aspects typically related to personal growth, such as, psychological well-being, social interactions, job related stress relief and enhancement in connectedness with friends and family through using Social media plat forms.

Findings of Mok, (2014) are also consistent with our hypothesis that usage of smart phone and psychological well-being are associated with each other. Sayers ,(2013). Stated that psychological factors are linked with usage of smartphones and one of them is that people enjoy spending time with different applications such as Facebook, Twitter, Instagram, WhatsApp and Imo which ultimately distant out them from the worries and fatigue . Tangmunkongvorakul, , et al ., (2019) stated that psychological well-being is associated with excessive use of Smart phone, despite its adverse impact, it provides opportunities to enhance the well-being by maintain good social relationships via different applications.

Kraut, et , al., (2012) suggested that females use smartphones more than males and majority of them spend time on different social applications such as Facebook, Snapchat, Instagram etc which makes them feel contented. Moreover, it helps them to get escape from the worries of outer world and they enjoy spending leisure times with their friends and family active through different social apps. Similar findings were also explained by (Lee, 2011) suggesting that utilization of Social media application leaves Positive effect on the user's mind and made them feel peaceful.

Berkman (2001) also stated the same results that maintenance of intimate relationship through Social Media applications helps people specially females, to feel happy, relax and psychologically well which also help them in the promotion of their relationships. Derks, et al., (2015) also stated that smartphone has enabled people to maintain connections while being away from home or from office . It has helped in the promotion of psychological well-being by utilizing different connectivity related platforms such as Facebook, Instagram, Imo etc. So, the result supports the hypothesis that smartphone usage helps positively in maintenance of strong relationship. (Muzaffar, et. al., 2019.) Focus of the study is also on the same construct that smart phone usage can influence the positive wellbeing of the working females.

\section{Theoretical Framework}

\section{Uses \& Gratification Theory}

The Uses and Gratification theory by Elihu Katz and Jay Blumler( 1970) explains the effects of the media/Social media on people. It explains how people use 
the media for their own need and get satisfied when their needs are fulfilled. In other words, it can be said that the theory argues what people do with media rather than what media does to people. There are several needs and gratification for people.

Affective needs: It includes all kinds of emotions, pleasure, and moods of the people. People use media / social media to satisfy their emotional needs.

Personal Integrative needs: This need is related with is the self-esteem. People use media, social media (Via Smart Phone) to reassure their status, gain credibility and stabilize.

Social Integrative needs: It encompasses the need to socialize with family, friends, and relations in society. For social interaction nowadays, people do not seem to gather socially during weekends instead they have turned to social networking sites on the internet such as Facebook, Twitter, and Tumblr etc. to satisfy their needs.

Tension free needs: People sometimes use the media as a means to escapism from the real world and to relieve from tension and stress

\section{Theory of Psychological Well-Being}

Carol Ryff in ( 1989) presented the theory of psychological wellbeing and explained the idea as a dynamic concept that includes subjective, social, and psychological dimensions also including health-related behaviors. According to Ryff Psychological Well-Being is composed of six dimensions related to individual's life including (a) Self-acceptance (b) Personal growth (c)Autonomy (d) Purpose in life (e)positive relationships and (f) environmental mastery. Current study also used the same theory in support to explain the concept of Psychological Well-being. As, the objectives of the study focused on identifying the impact of smartphone usage on psychological well-being, so the theory seems much relevant as, it provides a rich explanation of the personality constituents as well as factors associated with the mental health of human beings.

\section{Material and Methods}

\section{Research Design}

The study adopted Quantitative research design collection of data in order to best understand the variables Smart Phone usage, Psychological Well-being and their relationship. Survey Research method was used for data collection. According to Saunders, Lewis and Thornhill (2003) survey methodology is the best way to measure attitudes and to describe behavioral patterns as present study was about Smart phone using behaviors with relation to its impact on psychological being among working women employed in different institutions such as schools, colleges , universities, banks etc of Punjab Province in Pakistan. 


\section{Participants of the Study}

600 Participants were selected for the study. All the females working in different spheres of life such as schools, colleges, universities, banks and other corporate sectors in Punjab Province of Pakistan . Data was collected from different cities including (Sialkot, Lahore, Gujranwala, Multan, Faislabad and Bahawalpur).

\section{Frequencies and Percentages of Demographic Variable (Socioeconomic Status)}

Table shows the frequencies and Percentage of Socioeconomic status of respondents. $13.5 \%$ of the respondents had income between 10,000-20,000 PKR/- , $18.7 \%$ had income between 20,000-30,000 PKR/- , 22.7\% of respondent's income ranged between 30,000-40, $000 \mathrm{PKR} /-$, 13.5\% had income between 40,000-50, 000 PKR/- whereas, majority of the respondents $31.7 \%$ had income range above 50,000. Results showed that large number of respondents had stable economic background.

Table

Frequencies and Percentage of Income of the Respondent $(n=600)$

\begin{tabular}{ccc}
\hline Income & Frequency & Percent \\
\hline $10,000-20,000 \mathrm{PKR} /-$ & 81 & 13.5 \\
\hline $20,000-30,000 \mathrm{PKR} /-$ & 112 & 18.7 \\
\hline $30,000-40,000 \mathrm{PKR} /-$ & 136 & 22.7 \\
\hline $40,000-50,000 \mathrm{PKR} /-$ & 81 & 13.5 \\
\hline $50,000 \mathrm{PKR} /-$ more & 190 & 31.7 \\
\hline Total & $\mathbf{6 0 0}$ & $\mathbf{1 0 0 . 0}$ \\
\hline
\end{tabular}

\section{Measures}

Sample of the study was $(n=600)$. Data was collected from females working in different cities (Sialkot, Lahore, Gujranwala, Multan, Faislabad and Bahawalpur) of Province Punjab in Pakistan. Purposive sampling technique was used for data collection. Two standardized tools were used for measurement of variables. Smart Phone addiction questionnaire by Ching , et al., (2015) was used to assess the usage of Smart phone among working women of Punjab province in Pakistan. Ryff's Psychological wellbeing questionnaire by Ryff, et al., (1989) was utilized to assess the Psychological well-being of the Working Women in Punjab Province of Pakistan.

\section{Procedure and Analysis}

Data was collected through using Purposive sampling technique. Females $(n=600)$ working in different institutions such as Banks, Schools, Hospitals, and other organizations were approached and were given questionnaires and responses were obtained. Descriptive Statistics was used to obtain Frequencies, Percentages, Mean and Standard Deviation of the demographic characteristics. For Finding the relationship between Smart Phone Usage, Socio economic Status and psychological Well being ANOVA was employed. 


\section{Results and Discussion}

Descriptive analysis of variables (Social Media Usage and Psychological Wellbeing)

Table 2 suggested the descriptive analysis of variables. Analysis of variable Social Media usage suggested $(M=116.3$, S.D $=24.5)$ while for Psychological well being it was $(M=169.9$, S. $D=20.8)$.

Table 2

Descriptive of Social Media Usage scale and Psychological Well-being Scale

\begin{tabular}{ccccccccccc}
\hline & $\mathbf{N}$ & Range & Min & Max & Mean & SD & $\begin{array}{c}\text { Cronbach } \\
\text { alpha }\end{array}$ & Statistic & $\begin{array}{c}\text { Std. } \\
\text { Error }\end{array}$ \\
\hline $\begin{array}{c}\text { Social Media } \\
\text { Usage }\end{array}$ & 600 & 156.00 & 37.00 & 193.00 & 116.33 & 24.520 & 0.81 & -.067 & .100 \\
\hline $\begin{array}{c}\text { Psychological } \\
\text { Wellbeing }\end{array}$ & 600 & 150.00 & 90.00 & 240.00 & 169.90 & 20.808 & 0.78 & -.505 & .100 \\
\hline
\end{tabular}

Differences among the Income Level, Social Media Usage and Psychological Wellbeing of Women in Punjab, Province of Pakistan

Table 3 shows that there are significant differences in the use of social media and psychological wellbeing of working women. Table 3 and Figure 1 reveal that working women from low income groups use more social media as compare to the women from high income group. Moreover, Table 3 also indicates that the psychological wellbeing of low income group is also high as compare to the high income women. In this way, Table 3 and Figure 1 support us to argue that social media usage is interlinked with psychological well-being of working women. The respondents who use more social media are psychologically more satisfied. Hence, we find partial support to confirm $\mathrm{H} 2$ that social media use increases the psychological well-being of working women. Interestingly, our findings show that social media usage is becoming a source of psychological well-being for lower income class. These are the positive outcomes of social media development in Pakistan.

Table 3

ANOVA for Differences among the Income Level, Social Media Usage and Psychological Wellbeing of Women in Punjab $(\mathrm{N}=600)$

\begin{tabular}{|c|c|c|c|c|c|c|}
\hline & & $\mathbf{N}$ & Mean & SD & $\mathbf{F}$ & Sig. \\
\hline \multirow{5}{*}{$\begin{array}{c}\text { Social Media } \\
\text { Use }\end{array}$} & 10,000-20,000PKR/- & 81 & 126.01 & 23.31 & \multirow{5}{*}{8.894} & \multirow{5}{*}{$.000^{* *}$} \\
\hline & 20,000-30,000PKR/- & 112 & 123.50 & 21.36 & & \\
\hline & 30,000-40,000PKR/- & 136 & 110.55 & 25.03 & & \\
\hline & 40,000-50,000PKR/- & 81 & 112.56 & 25.07 & & \\
\hline & 50,000 PKR/-more & 190 & 113.72 & 24.21 & & \\
\hline
\end{tabular}




\begin{tabular}{|c|c|c|c|c|c|c|}
\hline & Total & 600 & 116.33 & 24.52 & & \\
\hline \multirow{6}{*}{$\begin{array}{l}\text { Psychological } \\
\text { Wellbeing }\end{array}$} & 10,000-20,000PKR/- & 81 & 174.56 & 15.88 & \multirow{6}{*}{3.280} & \multirow{6}{*}{$.011^{* *}$} \\
\hline & 20,000-30,000PKR/- & 112 & 173.97 & 18.36 & & \\
\hline & 30,000-40,000PKR/- & 136 & 169.01 & 20.54 & & \\
\hline & 40,000-50,000PKR/- & 81 & 167.16 & 27.47 & & \\
\hline & 50,000 PKR/-more & 190 & 167.32 & 20.41 & & \\
\hline & Total & 600 & 169.90 & 20.80 & & \\
\hline
\end{tabular}

Figure 1: Use of Social Media in Different Income Groups of Women

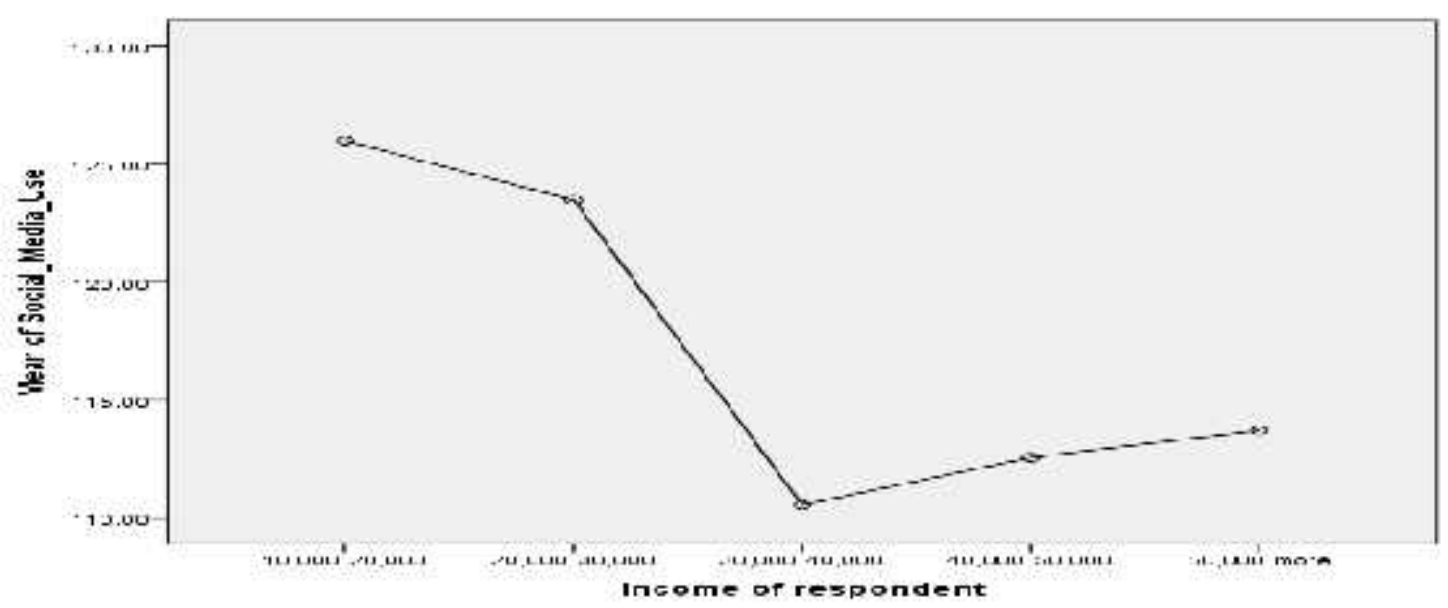

Figure 2: Psychological Wellbeing in Different Income Groups of Women

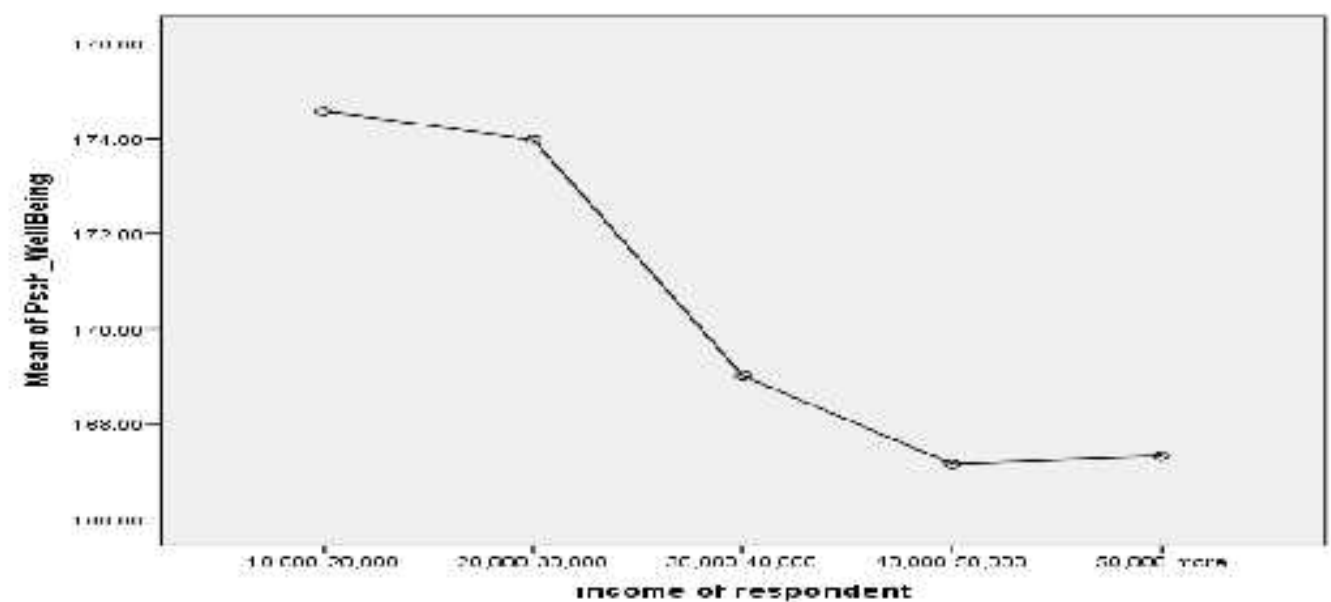

\section{Conclusion}

Purpose of the study was to find out the relationship between smartphone usage and psychological well - being of working women with different socioeconomic background in Punjab Province of Pakistan. In the study two 
hypotheses were tested (a) There would be a significant relationship between Smartphone usage and psychological well-being of working women in Punjab Province of Pakistan (b) Females from a high social class would have more psychological well-being as compared to the females from lower social class due to Smartphone usage.

Results of the study supported our first hypothesis that there is a significant relationship between Smart phone Usage and Psychological wellbeing of Working Women with different Socio economic background .The finding suggested that working women use Smart phones for relaxing themselves especially in their leisure times. It helps them in getting a relief from the tiresome routine caused by their jobs. Daily tasks related to job such as meetings, deadlines, emails etc made females feel burdened and that may trigger an unhealthy psychological pressure. Such pressures are not good for the well-being so, for maintain a distance from the work-related chores, females take the opportunity of using Social media with interest. There (on Social Media) they not only get information about current affairs, Sports, Fashion, Health and Beauty but through using Social apps they can easily stay enough with their intimate family members and friends. Consequently, the activity (using Smart Phone) results in achieving good and healthy leisure time necessary for Psychological well-being. Females develop sense of Love, Care, Compassion and belongingness by connecting with friends and family through using Social Sites which is essential for maintaining congenial relationships and also for a healthy mind. Berkamn (2001) suggested the same findings that there is a relationship between smartphone usage and psychological well-being. Moreover, strong bindings' and good relationships are also important for the maintenance of psychological well-being, which can be maintained by using smart phones. (Deneve , Cooper, King \& Pennebaker , 1998).

Vangelisti (2009) also explained the same findings that relationships maintained by using tools of communication are linked with psychological wellbeing. Karun, et al., (2012) suggested the same that usage of smart phones is associated with the well being of females, time spent on social media helps in relief from worries or burden caused by engagement in official activities. Mok , (2014) also explained that using smartphone and indulgement in social media helps in minimizing the tension, stress and strains caused by job related tasks .

Second hypothesis of the study did not get support from the results that females with good socioeconomic background indulge their selves more in using Smart Phone as compared to the females with Low Socioeconomic background. Results Showed a negative relationship between income, smartphone usage and related Psychological well-being. One possible explanation of this result could be that females having good economic background may indulge themselves in other activities such as Shopping, dining out, Gym , Exercise, Meditation because their income allowed them to do so but, females with meager resources may not afford these luxuries and only end up spending their leisure time in just watching TV , 
Movies, videos on YouTube, following the Fashion trends on Instagram and making connections Via Face book, WhatsApp and Imo. They find it convenient as well as less expensive to enjoy their leisure times. Uses and gratification theory also states that people use media or media related tools for their betterment, such as relieving the tensions, worries, etc .so, the study is consistent with the view of uses and gratification theory because females have shown better psychological well-being by using smartphone. Sense of relief, relaxation and promotion in psychological wellbeing has been found associated with the use of social media platforms.

Punjab is the largest province of Pakistan, majority of the population lives in this province. Due to rapid growth in population it is impossible for the Government to provide a standard living to a large number of its citizens. It is very hard for the residents to earn enough and sustain a good lifestyle. In such situation having expensive hobbies or enjoying time out from home is a mere dream. So, in this scenario middle class or lower middle class finds it easy to get an access to enjoyment or entertainment Via Smart phone.

In a country where proportion of working women is already very low, few gets the opportunity to earn equaling to men. Majority of females do low payment jobs ultimately resulting restricting the opportunities to enjoy the luxuries of life. In such scenario Smart phones have become a source of relief. It not only helps them to stay in touch with the office related activities but provide them a platform to stay connected with the friends and family. As a result, smart phone usage promotes their psychological well-being. Moreover, socioeconomic background plays an important role in the enhancement of psychological well-being. For sustaining a good lifestyle good income is essential. It not only enables people to get access to necessities of life but helps them to avail psychological wellbeing which is essential for the growth of human being.

\section{Implications of the Study}

This study has its implications in theory as well as practice. It will help working females to understand more about their Psychological wellbeing. It will make them understand the importance of psychological wellbeing to sustain and healthy and prosperous life. Findings are also crucial to understand the utilization of different social application to maximize the psychological well-being especially among females. Findings would help psychological health professionals to make people understand how leisure time activities are also beneficial for sustaining psychological wellness. They might create awareness among females to understand the importance of social relationships in the development of psychological wellbeing. Moreover, findings of the study would have its implications for policy makers that how a pro social environment could be created so that females feel relaxed while being at work. 


\section{References}

Adriana, B., \& James, G. P. (2005). Psychological predictors of problem mobile phone use. Cyber Psychology \& BehaviorVol. 8, No. 1, 9-51, https://doi.org/10.1089/cpb.2005.8.39

Tangmunkongvorakul, A. Musumari, P. M. Thongpibul, K. Srithanaviboonchai, K. Techasrivichien, T. Pilar Suguimoto, S. P. Ono-Kihara, M. Kihara, M. (2019). Association of excessive smartphone use with psychological well-being among university students in Chiang Mai, Thailand. PLOS ONE. 14. e0210294. 10.1371/journal.pone.0210294.

Berkman, F. (2001). Social Ties and Mental Health. Journal of Urban Health: Bulletin of the New York Academy of Medicine, 78, 458-467.

Bianchi A, Phillips J.G. (2005). Psychological predictors of problem mobile phone use. Journal of Cyberpsychology \& Behavior, 8(1), 39-51. http://dx.doi.org/10.1089/cpb.2005.8.39

Çetin, F.H., Pamuk, M., \&Donmuş, V. (2015). Ergenlerdeproblemli cep telefonukullanımiileakademikertelemearasındakiilişkide internet bağımlılığınına racılıkrolünün incelenmesi. ÇocukveGençlikRuhSağlığıDergisi, 22(1), 60-61.

DeNeve, K. M., \& Cooper, H. (1998). The happy personality: A meta-analysis of 137 personality traits and subjective well-being. Psychological Bulletin, 124, 197-229.

Derks, D., Van Duin, D., Tims, M., \& Bakker, A. B. (2015). Smartphone use and workhome interference: The moderating role of social norms and employee engagement. Journal of Occupational and Organizational Psychology, 88(1), 155177. https:// doi.org/10.1111/joop.12083

Elsobeihi, M.M., \& Naser, S.S. (2017). Effects of Mobile Technology on Human Relationships. EconStor Open Access Articles, 1, 110-125.

Hasin. F ., Hasan. A ., Musa, Hassan. (2018). Women Empowerment Model: Strategies To Overcome Challenges. 1068-1083. 10.4314/jfas.v10i1s.78.

Hong, S., Oxley, L., \& McCann, P. (2012). A survey of the innovation surveys. Journal of Economic Surveys, 26(3), 420-444.

Huppert ,F. A. (2009). Psychological well-being: Evidence regarding its causes and consequences. Applied Psychology: Health and Well-Being.1:137-164. DOI: 10.1111/j.1758-0854.2009.01008.x 
Karaaslan, A.İ., \& Budak, L. (2012). Üniversite öğrencilerinin cep telefonuözelliklerinikullanımlarınınvegündelikiletişimlerineetkisininaraştırılması . Journal of Yaşar University, 26(7), 4548 - 4571.

Kesgin, C., \&Topuzoğlu, A. (2006). Sağlı̆̆ıntanımı; başaçıkma. İstanbul KültürÜniversitesiDergisi, 3, 47-49.

Kraut, R. Sara Kiesler, S. Boneva, B. Cummings, J. Helgeson, V \& Crawford, A (2002). Internet paradox revisited. Journal of Social Issues, 58, 49-74.

Lee, G, L. (2011). Use of social-networking sites and subjective well-being: A study in South Korea. Cyberpsychology, Behavior and Social Networking, 14, 151-155.

Leung, L. (2015). Using tablet in solitude for stress reduction: An examination of desire for aloneness, leisure boredom, tablet activities, and location of use. Computers in Human Behavior, 48, 382-391.

Mok, J. Y. Choi, S. Kim, D. Choi, J. Lee, J. Ahn, H. Choi, E. Song, W. (2014).Latent class analysis on internet and smartphone addiction in college students. Neuropsychiatr Dis Treat. 10:817-828, https:// doi.org/10.2147/NDT.S59293

Muzaffar, M. Chodhry, S. Afzal, N . (2019). Social Media and Political Awareness in Pakistan: A Case Study of Youth. Pakistan Social Sciences Review,3(2),1-13, doi:10.35484/pssr.2019(3-II)01-13

Ryan, R. M., \& Deci, E.L. (2000). Intrinsic and extrinsic motivations: Classic definitions and new directions. Contemporary Educational Psychology, 25, 54-67. Retrieved from : http://dx.doi.org/10.1006/ceps.1999.1020

Ryff, C. (1989). Happiness is everything, or is it? Explorations on the meaning of psychological well-being. Journal of Personality and Social Psychology, 57, 10691081.

Sayers, V. (2013). The Powers: A Novel. Northwestern University Press.

See, A. A., \&Lasikiewicz, N. (2013). Smartphone use and work related wellbeing. In Proceedings of the International Conference on Managing the Asian Century (pp. 319-326). Springer, Singapore.

Silva, V.C. ( 2012) . iPhone sales boost smartphone market in 2011: Retrieved from :Gartner. http://www.mis-asia.com/tech/mobile-and-wireless/iphone-salesboost-smartphone-market-in-2011-gartner/ [9.11.2012].

Van Deursen, A. J., Bolle, C. L., Hegner, S. M., \&Kommers, P. A. (2015). Modeling habitual and addictive smartphone behavior: The role of smartphone usage types, emotional intelligence, social stress, self-regulation, age, and gender. 
Computers in human behavior, 45 (2015), 411-420.

https://doi.org/10.1016/j.chb.2014.12.039

Vangelisti, A. L. (2009). Challenges in conceptualizing social support. Journal of Social and Personal Relationships, 26(1), 39-51.

Yilmaz, G., Şar, A.H., \&Civan, S. (2015). Ergenlerdemobiltelefonbağımlığıilesosyalkaygıarasındakiilişkininincelenmesi. Online Journal of Technology Addiction \& Cyberbullying, 2(2), 20-37.

Yılmaz, M.F. (2013). Üniversite öğrencilerinin psikolojikiyioluşlarınınproblemli internetkullanımıvebazıdemografikdeğişkenleraçısındanincelenmesi.(Yükseklis nstezi, Anadolu ÜniversitesiEğitimBilimleriEnstitüsü, Eskişehir). https:/ / tez2.yok.gov.tr adresindenedinilmiştir. 